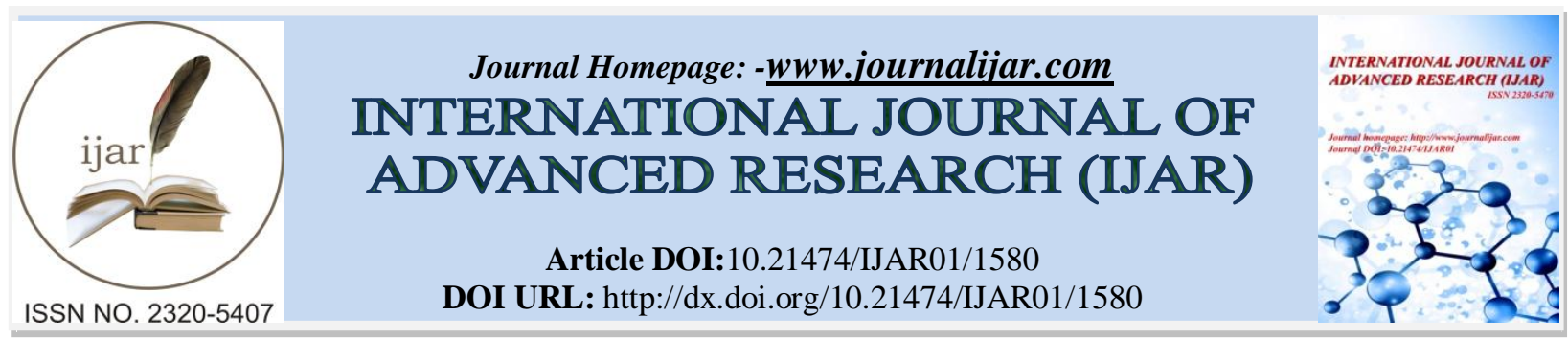

RESEARCH ARTICLE

\title{
IDENTITY CONFLICT AMONG DALIT IN THE POLITICAL SYSTEM OF INDIA.
}

Dr. Bina Rai.

Assistant Professor (Political Science) R.G. (P.G.) College, Meerut, 250004 Uttar Pradesh, India.

\section{Manuscript Info}

Manuscript History

Received: 13 July 2016

Final Accepted: 16 August 2016

Published: September 2016

Key words:-

Aarakshan, Bahujans, Bourgeois, Dalit,

Deprived Sections, Grudgingly,

Liberation

\section{Abstract}

On the $15^{\text {th }}$ August 1947 , India got her independence after a long prolonged struggle. During this freedom movement all castes, religion directly or indirectly participated and sympathized with struggle for freedom. Even Scheduled Castes also played important role in freedom struggle. Several Dalit leaders especially from South India also concentrated on the social and political awaking, besides attainment of socio-political rights. And now the political consciousness among Scheduled Castes is so high in comparison to their past that they know their political rights and do not take things themselves lying down. Parallel to others in fact they assert their political demands. They are also divided into several political groups. Interestingly they have been observed to be well informed about the qualities of a political party. They also know which of the political parties is likely to work their interest. And that is why they do not believe in one party or one political leader, but believe in different political parties and leaders. So those have become more opportunistic. Now Scheduled Caste has become new political identity.

Copy Right, IJAR, 2016,. All rights reserved.

\section{Introduction: -}

The general and specific features of the interaction between politics and the social structure characterize the framework of politics in any democratic society. The general features of politics in all democratic societies are that it intervenes to influence society and it also reflects the social reality. India is attempting reconciliationsbetween modern democratic political systems with a social system, which has its firm foundations in ancient culture. A specific feature of the development of contemporary Indian society is that all basic changes have been initiated by the Indian State. The Indian State is the agency of change in the society, and for performing such a Central role the State seeks its legitimacy through the democratic verdict of the people. Further, large masses of the people suffer from social and economic discriminations, and they look to the State functionaries for protection and survival while those who belong to the vulnerable strata of society seek protection from the State, the privileged and powerful seek to control State institutions and resources for protection and promotions of their material interests. The discipline of political science in India was long dominated by the elite among the upper castes and they still continue to have a hegemonic grip on the production and regulation of political science discourse. This decade along with the previous decade is a witness to the challenge thrown to Brahmanical political science by the non-Brahmanical groups. Gopal Guru, in his article "How Egalitarian are the Social Sciences in India?" unhesitatingly articulates how this is played out in the form of an implicit distinction made behind closed doors between 'Theoretical Brahmanism' and 
'empirical sudras' (2002:5003). He illustrates the complex discursive and non-discursive mechanism that is instituted in order to maintain the status quo. Indian model of democracy has led to an expansion of the political center from its modernist citadel outward toward society and its diversities. In the Human Development Report 1994, community security is an important ingredient in 'human security' - people derive security from their membership in a group -a family, a community, an organization, a racial or ethnic group that can provide a cultural identity and a reassuring set of values. At the same time 'community' affiliation may threaten security -'traditional communities can also perpetuate oppressive practices. The consensus hammered out in the Constituent Assembly reflected other calculations of political realism. The very fact that after Independence India continued to be a patchwork of diverse regional, religious, caste and tribal groups argued for an accommodative approach to building coalitions capable of ensuring national integration.During Nehru period in which the foundations of India's modern industrial economy were built -the centre was greatly limited in what it could accomplish by way of institutional changes to help the poor in the vast rural sector. The leaders of the state government, although virtually all congressmen until 1967, either belonged to or depended upon locally dominant landholding castes to mobilize the rural vote and win state and national elections. The names of these castes and even their ritual status varied from region to region, as did the configuration of thee coalitions they put together. It is in-fact, arguable that politics in Nehru period as a whole is best understood as a continuum of the Raj. The politics of elite accommodation identified with the 'Congress culture' did not disappear all at once. In a large number of states, where politicization of the disadvantaged lower castes and poorer classes was further advanced, the competition for political and state power was carried out by social groups banded together into Backward Classes and Forward Classes in contours first shaped under the British Raj.The political mobilization of the Backward, Scheduled Castes or Classes, whether pursued by regional or national political parties, rested on appeals to caste sentiments among cognate groups that cut across class differences to maintain the segmentation of the poor around distinctive social, ethnic and religious categories. The political divisiveness of this approach was latest serious in the states of South India where the Forward Castes had themselves emerged from the landowning Shudra peasantry, and where backward Hindus demanded a share in the privileges of dominant groups without seeking to displace them. In Tamil Nadu, the subnational Tamil cultural identity was associated with a community ideology that measured caste-Hindu privileges mainly against the 'unprivileged' of Scheduled Castes.

Dalit Identity:The local politics is dominated by the dominant castes in majority. A democratic government is based on election, which in turn requires the support of the majority of the people. So the election nowadays is highly influenced by the people who form the majority in a particular constituency. Therefore, time-to-time they have to seek the help of the other castes also. Here the leaders of both the castes perceive that although each scheduled castes separately and individually not form major group though untedily they constitute one solid block under the banner of 'Dalits' or Scheduled Castes and then forms the most powerful group in terms of its numerical strength. Half of the scheduled castes aware of the name of Shri Jagjivan Ram, although they could not tell portfolio he held in the Union Cabinet. All of them were well acquainted with the local leaders of their own castes, i.e. Sri Yadunandan Prasad, Sri Chandrado Kiran, Sri Sataydeo Arya, Sri Ganga Ravida, Kalicharan Choudhary, Ramchandra Bhati, Ram Narayan Shashtri,Bhole Paswan Shashtri, Ram Vilas Paswan etc. But it is also noteworthy that they do not support blindly the leaders of even their own caste. 'Elections are just business' is the common belief of the people belongings to the scheduled castes, they thinks that present elections are completely based on casteism, money and might. It has become a tragic fact of modern political life that political parties take the help of the scheduled castes only to gain popularity and not to help them in turns. The four decades of our Independence has experienced the scheduled castes the lesson that their condition has hardly improved. All political parties existing in India hold the opinion that they are all the same. Dalit politics in the urban sector seems to have become much more contingent, fluid and flexible. This new form of politics, which is more localized and ad hoc in its expression, explains the fragmentary context, which can no longer provide a coherent narrative about any politically grand solidarity of the subaltern, including the Dalit one. At the theoretical level, this kind of localized and community based Dalit politics has thrown up a new political concept like authenticity (Joseph 1998). This kind of new politics, however, has been endorsed by one of the prominent Dalit leaders who said that "caste is no more important in understanding the urban politics because there is no casteism in the urban centers although caste continues as a useful cultural source to hold the community together. * The Dalit political parties seem to have lost the historical role of mobilizing the dalit for the final takeover of the state. These parties do not seem to have any vision of emancipatory politics except to become an appendage of the dominant parties or bargain for the spoils of power through becoming a part of national collation politics. At the moment, there is another rather weak trend within dalit politics which indicates that the dalit are nauseous of radical politics and power. This political reflected in the dalit notion of state and nationalism (Nigam 2000). Hence, this notion of new Dalit politics identifies caste, religion, good 
morals, justice, family and literature as institutions of discipline and power that are to be resisted. Such an understanding of politics, which avoids any kind of organization of force around any kind of institutionalized power, in effect, also eschews the contestation of wider political structures, which basically have a symbolic relationship with the local centres of power. However, it is true that in recent times such grand politics of the toiling masses, by and large, has been absent from the Indian political scenario. In this case of leaders, particularly from the OBCs, Dalits and women, such mobility does not arise through the pains of sacrifice. Opponents do not think about the need for mutual recognition before they use their language that seeks to morally knock down the dalits, OBCs and women. The opponents of the Bahujan feel free to attack the dalits and women by using the worst possible language that seeks to ridicule and demonize the former. On the other hand, such attempts of the inferiorization of dalit leaders by also another also call into question the 'Thesis of Authenticity' as advanced by some scholars (Pandian 1998). A number of recent studies have brought out, in similar ways, the continued dominance of the upper castes (and virtual absence of Dalits, Adivasis and other disadvantaged communities) in media houses, corporate boards, and judicial institutions. Obviously, this does not help to ensure that concerns and views of dalits and adivasis are adequately represented in public debates. Mainly there are three layers of the politics of Dalit identity in the present times. The political and ideological equation of the inner conflicts, struggles and tensions in these three layer is separate matter.

1. Layer is organizing the Dalit with political consciousness through the caste factor. It is present in almost whole country with minor differences. This is attracting ordinary dalit by making an issue of the oppression and exploitation in the name of casteism in the past. This casteist politics is more dangerous and oppressive.

2. Layer is of political section with Brahmanical mentality whose main motive is to make dalit serve their purpose by whipping up their desires. This section wants to keep dalit won over through the assurance of security while keeping him tied to sub-conscious of insecurity.

3. And last is that which does not use dalit but links the politics of dalit to his liberation. This liberation is, in fact, linked to all those deprived sections, which is not single layered. Through, this creates a paradigm by linking the discourse of human liberation of a Dalit human, unattached to proletariat. This third side is weak in the present time but in future this can become the basis of authentic identity politics.

\section{Problems behind Identity: -}

The issue of dalit identity in social, economic and political context has become so important nowadays, that it has been affecting the thinking processes of all opinion making and decision taking authorities in India. Even though, originally it was social problem, now it has attained significance resulting in far-fetching consequences in deciding the future of Indian polity.

In this present times dalit politics or the politics of dalit identity is getting its all from this corrupt bourgeois value system. There is no project of the all-round dalit liberation in the programmes of the political parties associated with it. They lack any clear policy or political programme, which can provide a parallel model of social justice for dalit. Our society indulges in the politics has done in the corridors of power exactly what bourgeois politics does. The notion of identity authentication is not free from problems. In fact, it becomes all the more problematic when viewed in the context of politics. As far as understanding new dalit politics is concerned, the notion of identity has been premised on the association with important notions like difference, disassociation, cultural specificity and above all celebrated particularity. Thus identity authentication is an expression of particularity, is being juxtaposed by certain dalit-Bahujan scholars against universality. It treats the political expression of this subject as natural as opposed to artificial. As far as identity is concerned, it offers a certain amount of guarantee against its unconditional dissolution. But at the same time this notion of identity that seeks to define new dalit politics suffers from the following rather serious limitations.

1. Since it essentializes the particular mode of dalit politics, it remains fettered by the completely narrow localized vision of emancipatory politics. It therefore remains both sociologically and ideologically blind towards the historical necessity of opening up a social/ideological corridor with the other social reality that demands its radical alternation for the same reason that the authentic group is demanding the local level.

2. Since the insistence on identity seeks in a package deal, severance of revolutionary links with other radical political subjectivity, it caused damage to dalit politics at two levels. Its framework of absolute relativism tends to malapportion the political energies of dalit within localism. With such a kind of new politics, the adversaries feel absolutely comfortable, as such politics does not have the plan and potential to create a grand political project alone can ensure the imminent collapse of adversaries. 
This kind of opportunistic politics, however, does not face any challenges from the dalit common masses as they finally end up supporting such dalit political groups or the educated lot choose to remain aloof from dalit politics. The social base dalit politics is very diverse, thus containing mutually exclusive elements that in effect make any homogenized version of politics impossible. For example, the rising dalit middle class has a very elitist and puritan notion of political life, which makes it completely disdainful of any formal politics including dalit politics. They often argue that politics in general and dalit politics in particularly is bad and it is a game of corrupt politicians and hence they prefer to keep out of such politics. On the contrary, they would take pride in telling others that all members of their family are well placed in terms of employment and keep away from dalit politics. They would not support the social activist financially nor would they dedicate one of their family members as a full-timer for the large emancipatory cause of their society. Thus on the moral ground the middle class among the dalits is found to be completely impoverished. Other problems related to education, awareness, poverty, rural backwardness keep away their identity in politics.

\section{New Trends in Politics for Dalit Identity: -}

In contrast to the Ambedkarite who according to Anupama Rao (2009) have come to represent the caste question as one of political subjectivity in India. The radical diversity and plurality amongst the dalit in itself comprise a question about the caste system which at the same binds them together as a singular entity yet challenges them to revolt against it. This rise to reckoning of the movement is also thanks to the dogged universalism put forth by all dalit groups till the arrival of Kanshiram and Mayawati. They grafted their own strategy of 'social engineering' on the dalit ideologies of liberation to make an appeal to the emancipation of "sarvasamaj" or of all castes. The attachment of untouchables to congress during the 1930s and 40s was far less than is sometimes assumed. From 1952 until 1989 with the exception of the post-emergency election of 1977, dalits tended to function in both national and state elections as a 'vote bank' for congress and other parties too. In rational terms and here their situation was similar to that of Muslims there was little electoral choice open to dalits in most part of country. If the Left had developed more strength outside what become its strongholds in West Bengal and Kerla, the untouchable attachment to Congress might have been less. Within Congress the importance of the dalits vote did not translate itself into great influence for individual dalits in either the organization or the ministry.In particular, the building of the compensatory discrimination system arose more from the arithmetic of elections and the goodwill of sections of the elite than from the efforts of Dalit parliamentarians. Babu Jagjivan Ram was alone as a Scheduled Caste politician in becoming genuinely national figure through Congress. There is couple of Chief Ministers -one of them was Bhole Paswan Shashtri who three times held this position in Bihar, but he made no deep mark on even State politics. But none has had either a long period at the apex of ministerial service or any substantial political base. Just why this is? Perhaps it is to be expected that a collection of caste distinguished by their overall subordinate would not produce the highest crop of educated, experienced and generally talented politicians. On the other hand, issues of talent and preparation for public office can scarcely constitute the primary explanation for the low representation of dalits at the highest political levels. This is the dialectic embedded in the issue of dalit representation in contemporary politics. Thus, it is reasonable to assume that greater dalit representation at the highest levels would produce outcomes more favorable to their own people than occurs through government dominated by the high castes. Until the recent emergence of the Bahujan Samaj Party (BSP), the only post-independent example of a party centered on dalit was the Republican Party of India (RPI). This was the final political vehicle devised by Ambedkar, though its formation in reached fruition only some months after his death. We have a one point programme-take power.' This statement by the office secretary of BSP, illustrates the principal thrust of the strongest Dalit organization to emerge in the 1980s. And, indeed, the BSP under Kanshi Ram's leadership, was envisaged precisely as party of dalits backwards and minorities, with dalit playing a vanguard role; and from the outset, it has been projected as an organization based on practical politics and not on sentiment. Power was within its grasp precisely because the Dalits and Shudras together constituted a majority. We are 85\%-we don't need to make any alliances; we can rule on our own'. This statement echoes the view, which ArunKamble had propagated as a leader of the Dalit Panthers. For some time, it was the BSP which was most successful in capturing the new anti-caste upsurge. A look at the discourses of Kanshi Ram's principle slogans illustrates BSP's appeal: Brahmin bania Thakur chor/baki sab DS$4 *$ in fact contains a formulation of the alliance strategy, identifying the 'main enemy' and the 'allies'; 'vote hamara raj tumharanahichaleganahichalega' is a clear statement of the thrust to political power, while the most recent 'vote se lenge PM/CM, aarakshan se SP/DM' illustrate the limited nature of the drive to power.

In 1977 Mayawati had made contact with Kanshi Ram, while she was student. Her opponents in Bijinor included Ram Vilas Paswan, and Meira Kumar. But by 1989, BSP had solid organizing work. Kanshi Ram had prepared the ground carefully in U.P., Bihar, Madhya Pradesh, Punjab, Delhi and parts of Haryana. In June 1995 early on the 
much younger Mayawati was properly regarded as lieutenant of Kanshi Ram, to whom popular accounts suggest she is romantically as well as politically linked. But Mayawati has been able to bring a charisma and liveliness to the hustings that Kanshi Ram himself has lacked. In short Mayawati has become both considerably popular and also a force to reckon with. A major transformation had taken place in Indian Politics. Congress hegemony had apparently vanished for good not only in the sense of share vote, it also in the sense of that its ideology. In 1990s the drive towards Dalit political expression has continued, not only with the ongoing growth of the BSP, but also with the formation of new parties and political fronts. The BSP remains the largest Dalit based party. But this is perhaps only a temporary situation. Dalits and other 'low' castes have been taking their first steps towards political power/identity.

\section{Conclusion: -}

This community is now richer, educated and bolder than when gave it support to Jagjivan Ram. But Kanshi Ram and more recently Mayawati have also worked hard to dispel the notion that their party represents only the Dalits. They do represent a more aggressive attack on the order of social orthodoxy than has previously been seen from participants in the mainstream of Indian electoral politics. Kanshi Ram shown that a person of Dalit origins can lead a party that wins seats at the ballot box and is not afraid to form a Government that puts the interest of the most subordinated Indians at its very centre. Throughout India it will be more difficult to ignore the interest and identity of Dalits.In any case, the result is that the dalit derive for identity through politics is still in early stages, dependent for programme and political direction on mainstream parties. While a lot of progress has been made to improve the status and identity of dalits, a new generation of dalit leadership has emerged in India. However, due to other problems in India, their agenda gets twisted, misinterpreted and even ridiculed. Many dalit do not wish to be identified as dalit for obvious reasons and the Dalit community is losing valuable leaders to neo-brahmanism. Even the party who identified as Dalit party is not aware for dalits identity. The big question raised in BSP after Mayawati who would be the next? $2^{\text {nd }}$ line of leadership is absent. BSP Supremo Mayawati didn't do anything like Kanshi Ram who launched and promoted her in politics. In other words, why do the same leaders continue to occupy politics and do not make space for newcomers? There could be two reasons that can explain this stagnation of the dalit leadership.

1. The established dalit leaders have not developed any other additional centres of power that could be used during the times when these leaders could not manage to stay in power. This lack of control over the subsidiary power centres makes these leaders completely dependent on dominant politics, while this is not the case of the nondalits who have created other centres of power like factories, cooperatives and educational institutions. Dalits do not have such additional power centres.

2. The second rank leadership does not revolt against these leaders as it is given a free hand to make alliances with any party during the election.Also, the leaders tend to ignore the workers who want to make the most of these alliances during the election. The party leaders do not insist that local level party workers should stick to the consistent ideological position in their local politics.

The common people have been seen to be grudgingly supporting the dalit leaders. This grudging acceptance emanates from the situation where dalits feel politically helpless. The dalits do not find any alternative; in fact they do not want to find one as it also work out to the political expectation of their patriarchal domination within the dalit situation. India's ruling class does not want to abolish untouchability because it provides a lot of socio-economic benefits, and more than anything else, the bulk votes of the dalit to the ruling class. They are its 'vote bank', which gives interest free loans and even BSP doing too. Dalit leaders in other parties like Ashok Gahlot, Chirag Paswan are not become national and dalit figure. Thus the politics of dalit identity today can be defined as 'what is personal is social' and this definition of politics needs to be seriously challenged as a part of the dalit emancipatory strategy and politics.

\section{References: -}

1. This was the public speech that was delivered by one of the RPI leaders, Mr. Prakash Ambedkar, on $6^{\text {th }}$ December 1999.

2. *DS-4 refers to the Dalit, Shoshit, Samaj Sangarsh Samiti

3. Bally, Lahori Ram (1997): "Dr. Ambedkar: JeewanAtey Mission (Punjabi)" BhimPatrikaPrakashan, Jalandhar

4. Bhargava, Rajeev, BagchiArun Kumar \&Sudarshan S (Ed.-2010): Multiculturalism, Liberalism and Democracy" Oxford India, New Delhi. 
5. DattaPradip Kumar \&Palshikar Sanjay, (Ed. 2013): Indian Political Thought: ICSSR Research Surveys and Explorations, Vol.3, Oxford India, New Delhi.

6. Dreze jean \& Sen Amartya (2014): "An Uncertain Glory- India and its Contradictions"

7. Gore, M.S. (1993): "The Social Context of an Ideology: Ambedkar's Political \& Social Thought" Sage Publication New Delhi

8. Joseph, Sarah (1998): Interrogating Culture, SagePublications, New Delhi

9. Jayal, Neeraj Gopal (ed. 2001): 'Democracy in India- themes in politics' Oxford India, New Delhi.

10. Sadangi, Himansu Charan (2008): "Dalit the Downtrodden of India" Isha Books Publication, New Delhi

11. Sharma, K.L (2001): "reconceptualising- Caste, Class and Tribe" Rawat Publications Jaipur \& New Delhi

12. Sharma, K.L.(Ed. 1992): Social Stratification in India" New Delhi

13. Vora, Rajendra\&PalishkarSuhas (Ed. 2004): "Indian Democracy-Meanings \& Practices" Sage Publications, New Delhi

14. Yadav, Mamta (Ed. 2010): "Dalit and Politics" Omega Publications, New Delhi

15. The mainstream NGO discourse in the country floats and supports this kind of notion of dalit politics. Pandian, M.S.S. (1998) 'Stepping Outside History' in Partha Chatterjee (ed.), Wages of Freedom, OUP, New Delhi

16. Dalit Humanism, Literature and 'Technology of Deification'- Understanding the Politics of Matang Samaj by K.V. Cybil in 'Economic \& Political Weekly' December 21, 2013 